\title{
Influence of Selected Dietary Plant Extracts on Productive, Physiological, and Viral Immunological Response of Broilers
}

\author{
S. J. Zamil, K. I. A. Al-Shammari*, \& E. M. Mohammed \\ Department of Animal Production Techniques, Technical College of Al-Mussaib, \\ Al-Furat Al-Awsat Technical University, Babylon, Iraq \\ *Corresponding author: com.kr4@atu.edu.iq/ kar_msc2010@yahoo.com \\ (Received 31-01-2020; Revised 11-04-2020; Accepted 21-04-2020)
}

\begin{abstract}
This experiment was implemented to evaluate the influence of 3 plant extracts involving garlic (GC), cinnamon (CN), and black cumin (BC) powders in broiler chicken diet from 1-42 d on productive, physiological, and immunological traits. In total, 240 birds were assigned into 4 groups, each with 3 replicates. In the control group $(\mathrm{CO})$, the chickens were fed with a balanced diet. Experimental groups were composed by supplementing the diet with $4 \mathrm{mg} / \mathrm{kg}$ of diet for each $\mathrm{GC}, \mathrm{CN}$, and BC. At 3 and 6 weeks, GC, CN, and BC groups achieved higher body weights, weight gains ( $\leq \leq 0.01)$, and low feed conversion ratio. GC group recorded low feed intake $(p \leq 0.05)$ compared to the $C O$ and the other groups from 1 day- 6 weeks. GC, CN, and BC groups registered high $(\mathrm{p} \leq 0.01)$ PCV value and lower cholesterol and triglycerides concentrations in serum compared to the $\mathrm{CO}$ group. Reduction and increase $(p \leq 0.01)$ in serum glucose and protein for $G C$ and $C N$, and $C N$ and $B C$, respectively, were recorded. High levels of triiodothyronine (T3) $(\mathrm{p} \leq 0.05)$ and thyroid-stimulating hormone (TSH) in GC and $\mathrm{CN}$ groups and all treated groups had high concentrations of thyroxine (T4) $(\mathrm{p} \leq 0.01)$ compared to the $\mathrm{CO}$ group. Moreover, a clear augmentation in serum antibody titer against Newcastle and Gumboro diseases in GC, $\mathrm{CN}$, and $\mathrm{BC}$ compared with the $\mathrm{CO}$ group was observed. It was concluded that GC, CN, and BC extracts at the present level may be used to enhance the productive, physiological, and viral immunological characteristics of birds.
\end{abstract}

Keywords: garlic; cinnamon; black cumin; broiler chicken

\section{INTRODUCTION}

There has been a growing number of scientific papers regarding the use of plant extracts since a ban on antibiotics uses as growth promoters in animal feed were introduced in 2006. Therefore, plant extracts and their derivations are used as alternative supplements and have become of exceptional interest in poultry production (Abbas \& Ahmed, 2010; Brzóska et al., 2015; AlShammari et al., 2017). Plant extracts (spices and herbs) and their phytobiotics effects (bioactive constituents present in essential oil) can be incorporated into poultry diets to boost the productivity, physiology, and even welfare of birds. In monogastric animals, plant extracts have a diversity of Phyto biotics which are reported to act as stimulating agents for appetite and enzymatic secretions, and with prebiotic, immunological, antimicrobial, and prophylactic activities (Wenk, 2003; Lee et al., 2004; Vidanarachchi et al., 2005). Also, it is well known that many dietary-plant extracts can adjust the intestinal microflora strongly, which in turn, can modify animals' response to diet and homeostasis (Wenk, 2003). These plant-derived materials have their physiological roles in body cells and tissues because they are considered as less toxic and residue-free and have been proven to be the optimal feed supplements in comparison with synthetic and antibiotic compounds in the diets of farm animals (Vidanarachchi et al., 2005).

Garlic (Allium satioum L) is a popular spice which has a pungent quality and has been used as a culinary spice in most of the traditional cultures since it contains a multitude of active components such as, allicin, s-allyl cysteine, ajoene, and diallyl sulphide (Rahmatnejad \& Roshanfekr, 2009). These compounds have a variety of advantages, most of which have been confirmed scientifically, e.g., antithrombosis, anti-atherosclerosis, antimicrobial, hypolipidemic, anti-diabetes, anti-hypertension, and antimicrobial functions, etc. (Mansoub, 2011; Puvača et al., 2015). It was proven that garlic, as a natural feed additive, has improved growth, feed conversion ratio, carcass quality, and health status (Stanaćev et al., 2011). It also lowers the number of triglycerides and low-density lipoprotein (Puvača et al., 2015) in broilers with hypocholesterolemia impact upon serum and the yolk of layer hens (Chowdhury, 2002). Additionally, garlic powder may inhibit ascites incidence because of its anti-hypertensive characteristics in the cardiac system without deteriorating broiler performance (Varmaghany et al., 2015). 
Cinnamon (Cinnamomum verum) is one of the oldest familiar herbal medicines which contains more than 300 active substances such as trans-cinnamaldehyde and certain biologically active compounds such as cinnamyl acetate, cinnamyl alcohol, carvacrol, and eugenol present in its essential oils. Eugenol and cinnamaldehyde are two substantial terpenoids found in cinnamon (Qin et al., 2003, Tajodini et al., 2015). The powerful capacity of cinnamon as anti-allergenic, antioxidant, antifungal, anti-inflammatory, and antiviral agents along with its blood purifying and digestion-aiding properties is attributed to these biological compounds (Tajodini et al., 2015).

Black cumin (Nigella sativa L.) is an aromatic plant. It has been applied in the treatment of several diseases over the course of 2000 years and has been exploited as a supplement in poultry feed because of its possibility to optimize performance via antimicrobial, antioxidant, and the other pharmacological properties found within (Kumar \& Patra, 2017). Ramadan (2007) mentioned active compounds in black cumin present in essential oil consisting of carvone, an unsaturated ketone, terpene or limonene also called carvene, p-cymene, $\alpha$-pinene, and nigellone. Thymol, thymoquinone, di-thymoquinone, and thymo-hydroquinone are pharmacologically effective constituents of the volatile oil (Ghosheh et al., 1999), while trans retinol, DL- $\gamma$-tocopherol, DL- $\alpha$-tocopherol, and selenium are among important antioxidants (AlSaleh et al., 2006).

The systematic approach with respect to the efficiency and safety of these plant-based substances and their active botanicals in the poultry industry has not been broadly researched. Further studies are required to improve the situation. Based upon the premise, the current study was carried out to assess the impact of garlic, cinnamon, and black cumin as phytogenic additives upon the performance characteristics, physiological, and immunological aspects of Ross 308 broilers fed the same levels of these dietary additives.

\section{MATERIALS AND METHODS}

\section{Experimental Design and Birds Management}

This experiment was conducted in the farm and laboratory facilities belonging to Al-Furat Al-Awset Technical University, Babylon, Iraq. The study ran for $42 \mathrm{~d}$. These plant extracts (Hennahub India, Sojat, Rajasthan/India) were purchased from the local market as a fine powder and mixed freshly into diets every three days. Two hundred and forty broiler chickens Ross 308 were housed in (1x2 m) floor pens with 3 pens (replicates) per group. The experimental groups were divided into 4 groups, 60 chicks in each group. The first group was the control group (CO) (no dietary supplement), and $2^{\text {nd }}, 3^{\text {rd }}$, and $4^{\text {th }}$ groups' diets were supplemented with $4 \mathrm{mg} / \mathrm{kg}$ garlic (GC), cinnamon (CN), and black cumin $(\mathrm{BC})$, respectively. All birds were fed ad libitum (Table 1) on uniform isonitrogenous and isocaloric diet based on NRC recommendation (NRC, 1994) and maintaining all healthcare and preventive measures during the experiment.

\section{Characteristics Studied}

The productive characteristics of birds involving live body weight and feed intake were recorded weekly and reported periodically to calculate weight gain and feed conversion ratio. At the end of the experiment, 9 birds per group ( 3 birds per pen) $(n=9)$ were bled. A blood sample was collected from the jugular vein and kept in non-heparinized plastic tubes to obtain blood serum. Blood samples were then centrifuged at 3000 RPM for 15 minutes to separate the serum. Subsequently, the serum was stored at $-20^{\circ} \mathrm{C}$ until biochemical and immunological analyses were conducted. From fresh blood, packet cell volume (PCV) was determined using heparinized microhematocrit capillary tubes (Haen, 1995). For serum biochemical evaluation, glucose, protein, cholesterol, and triglycerides levels were measured using commercial laboratory kits (Diagnostic Biosystems, Spain) and spectrophotometer VS721G according to methods coined by Burtis et al. (2005); Burtis et al. (2005); Friedman \& Young (2001) and Young (2000), respectively. Levels of thyroxine (T4), triiodothyronine (T3), and thyroid-stimulating hormone (TSH) in serum samples

Table 1. Diet formula and chemical composition

\begin{tabular}{|c|c|c|}
\hline Ingredients (\%) & $\begin{array}{c}\text { Starter } \\
\text { (1 day-3 weeks) }\end{array}$ & $\begin{array}{c}\text { Finisher } \\
(4-6 \text { weeks })\end{array}$ \\
\hline Yellow corn & 40 & 47 \\
\hline Wheat & 20.5 & 21.4 \\
\hline Soybean meal & 26 & 20 \\
\hline Protein concentrate ${ }^{(1)}$ & 10 & 8 \\
\hline Vegetable oil & 2 & 2 \\
\hline Salt & 0.3 & 0.3 \\
\hline Premix ${ }^{(2)}$ & 0.2 & 0.28 \\
\hline Limestone & 1 & 1 \\
\hline L-Lysine & - & 0.02 \\
\hline Total & 100 & 100 \\
\hline \multicolumn{3}{|l|}{ Calculated analysis } \\
\hline Crude protein (\%) & 22.20 & 19.30 \\
\hline $\begin{array}{l}\text { Metabolizable energy } \\
(\mathrm{kcal} / \mathrm{kg})\end{array}$ & 3006 & 3073 \\
\hline Calcium (\%) & 1.27 & 1.10 \\
\hline Available phosphorus (\%) & 0.41 & 0.40 \\
\hline Lysine $(\%)$ & 1.16 & 1.25 \\
\hline Methionine (\%) & 0.25 & 0.40 \\
\hline \multicolumn{3}{|c|}{$\begin{array}{l}\text { Note: } \\
\text { (1) (Holde Mix, Jordan) provided following nutrients per kg of diet: } 40 \% \\
\text { of crude protein; } 1 \% \text { of crude fiber; } 3.5 \text { of fat; } 6 \% \text { of calcium; } 2100 \text { of kcal } \\
\text { metabolizable energy; } 3 \% \text { of phosphorus; } 2.20 \% \text { of salt; } 3.25 \% \text { of lysine; } \\
3.50 \% \text { of methionine; } 3.90 \% \text { of methionine + cystine; } 40000 \text { of IU of vita- } \\
\text { min D3; } 15 \mathrm{mg} \text { of vitamin B1; } 3000 \mathrm{mg} \text { of vitamin B6; } 50 \mathrm{mg} \text { of vitamin } \mathrm{E} \text {; } \\
200 \text { of mg niacin; } 1000 \mathrm{mg} \text { of iron; } 6 \mathrm{mg} \text { of cobalt; } 800 \mathrm{mg} \text { of zinc; } 200000 \\
\text { IU of vitamin A; } 15 \mathrm{mg} \text { of vitamin B12; } 300 \mathrm{mg} \text { of vitamin B12; } 30 \mathrm{mg} \text { of } \\
\text { vitamin K; } 100 \mathrm{mg} \text { of biotin; } 100 \mathrm{mg} \text { of cupper, } 1200 \mathrm{mg} \text { of manganes; } \\
15 \mathrm{mg} \text { of iodine; } 2 \mathrm{mg} \text { of selenium and } 10 \mathrm{mg} \text { folic acid. } \\
\text { (2) (Poultry Premix, Belgium) provided following nutrients per kg of diet: } \\
9000 \mathrm{mg} \text { of methionine; } 200 \mathrm{mg} \text { of vitamin D3; } 250 \mathrm{mg} \text { of vitamin B1; } \\
500 \mathrm{mg} \text { of vitamin B6; } 5000 \mathrm{mg} \text { of vitamin E; } 5000 \mathrm{mg} \text { of iron; } 100 \mathrm{mg} \text { of } \\
\text { cobalt ; } 1250000 \mathrm{IU} \text { of vitamin A; } 2 \mathrm{mg} \text { of vitamin B6; } 200 \mathrm{mg} \text { of vitamin } \\
\mathrm{K} ; 2.5 \mathrm{mg} \text { of biotin; } 800 \mathrm{mg} \text { of cupper; } 100 \mathrm{mg} \text { of iodine; } 10 \mathrm{mg} \text { of se- } \\
\text { lenium; } 150 \mathrm{mg} \text { of folic acid; } 9.2 \mathrm{mg} \text { of magnesium; } 5.2 \mathrm{mg} \text { of zinc and } \\
4000 \mathrm{mg} \text { of choline. }\end{array}$} \\
\hline
\end{tabular}


were determined radio-immunologically by means of test kits (AccuBind ${ }^{\circledR}$ ELISA, USA). All samples were run in duplicate and kit calibrators, and controls were contained in each analysis. By using ELISA microplate reader (HumaReader HS, Germany), absorbance was measured at a specified value in the kit, with a reference wavelength of each analytical step (Braverman, 1996). To evaluate antibodies titer against Newcastle and Gumboro diseases, research kits (ProFLOK® NDV-T ELISA, USA, and ProFLOK® IBD-T ELISA, USA), were used respectively in compliance with manufacturers' protocol and instruction by using an automated microplate reader (BMG LABTECH, Germany).

\section{Statistical Analysis}

The data were analyzed statistically by ANOVA with a completely randomized design (CRD) using SAS Software (SAS, 2001). To find significant differences $(p<0.05)$ and $(p<0.01)$ among the groups' means, Duncan's multiple tests were carried out.

\section{RESULTS}

The influence of three supplementary levels of plant extracts (GC, CN, and $\mathrm{BC}$ ) on growth performances are shown in Table 2. The levels of GC, CN, and $B C$ had high significant $(p \leq 0.01)$ impacts on weeks 3 and 6 regarding body weight and weight gain from 1 day- 3 weeks and from 1 day- 6 weeks. From 1 day- 3 weeks, there was no significant difference in feed intake between groups fed diets with all plant extracts and the $\mathrm{CO}$ group. However, from 1 day to 6 weeks, birds fed diets supplemented with GC had lower $(p \leq 0.05)$ feed intake. Significant improvement (reduction) $(p \leq 0.01)$ in feed conversion ratio was noticed in birds fed GC, CN, and $\mathrm{BC}$ than those in the $\mathrm{CO}$ group at both ages (1 day-3 weeks) and (1 day- 6 weeks).

The birds fed diets containing experimental groups had high $(p \leq 0.01)$ significant impact on PCV value and low $(\mathrm{p} \leq 0.01)$ significant levels of cholesterol and triglyceride values than birds fed the non-supplemented diet (Table 3). In the same table, there was a low level $(p \leq 0.01)$ of glucose in GC and $C N$ and a high level $(p \leq 0.01)$ of protein in $\mathrm{CN}$ and $\mathrm{BC}$ compared with the $\mathrm{CO}$ group.

Table 4 revealed that GC and BC achieved high values $(p \leq 0.01)$ and $(p \leq 0.05)$ in T3 and TSH respectively, whereas all groups whose diet was supplemented with plant extracts recorded high values $(p \leq 0.01)$ in T4 compared with the $\mathrm{CO}$ group. The means of Newcastle and Gumboro hemagglutination-inhibition titers in birds fed diets containing plant extracts were significantly higher $(p \leq 0.01)$ than those fed the CO diet (Table 5).

\section{DISCUSSION}

\section{Growth Performance}

The accumulative increase in body weight and weight gain in the present data reflected the accumulatively positive reduction in feed conversion ratio (FCR) in birds fed diets based on GC, CN, and BC extracts. These results might be due to the availability of major natural bioactive elements found in essential oils of these extracts, e.g., allicin, sulfur-containing compounds in GC (Khan et al., 2012a; Puvača et al., 2015), transcinnamaldehyde in CN (Tajodini et al., 2015), quinine, carvone, carvene, $\alpha$-pinene, p-cymene, and nigellone in BC (Abbas \& Ahmed, 2010; Kumar \& Patra, 2017). These

Table 2. Productive traits of broilers fed on different sources of plant extracts (mean \pm standard error)

\begin{tabular}{|c|c|c|c|c|c|c|c|c|}
\hline \multirow{3}{*}{ Groups } & \multicolumn{8}{|c|}{ Variables } \\
\hline & \multicolumn{2}{|c|}{ Body weight (g) } & \multicolumn{2}{|c|}{ Weight gain $(\mathrm{g})$} & \multicolumn{2}{|c|}{ Feed intake (g) } & \multicolumn{2}{|c|}{ Feed conversion ratio } \\
\hline & 3 weeks $* *$ & 6 weeks** & $\begin{array}{l}1 \text { day-3 } \\
\text { weeks }\end{array}$ & $\begin{array}{l}1 \text { day-6 } \\
\text { weeks }^{* *}\end{array}$ & $\begin{array}{l}1 \text { day-3 } \\
\text { weeks }^{\text {NS }}\end{array}$ & $\begin{array}{l}1 \text { day-6 } \\
\text { weeks* }\end{array}$ & $\begin{array}{l}1 \text { day-3 } \\
\text { weeks }\end{array}$ & $\begin{array}{l}1 \text { day-6 } \\
\text { weeks }{ }^{* *}\end{array}$ \\
\hline $\mathrm{CO}$ & $617.50 \pm 3.50^{\mathrm{d}}$ & $2114.0 \pm 2.00^{\mathrm{d}}$ & $575.5 \pm 2.50^{\mathrm{d}}$ & $2072.0 \pm 1.00^{\mathrm{d}}$ & $876.5 \pm 6.00$ & $4182.0 \pm 9.5^{\mathrm{a}}$ & $1.52 \pm 4.00^{\mathrm{a}}$ & $2.01 \pm 3.01^{\mathrm{a}}$ \\
\hline GC & $684.50 \pm 3.55^{\mathrm{b}}$ & $2349.5 \pm 3.50^{\mathrm{b}}$ & $642.5 \pm 1.50^{\mathrm{b}}$ & $2307.5 \pm 2.50^{\mathrm{b}}$ & $883.5 \pm 6.00$ & $4094.0 \pm 9.5^{b}$ & $1.37 \pm 5.01^{\mathrm{b}}$ & $1.77 \pm 2.01^{\mathrm{c}}$ \\
\hline $\mathrm{CN}$ & $692.50 \pm 2.50^{\mathrm{a}}$ & $2395.0 \pm 2.30^{a}$ & $650.5 \pm 1.50^{\mathrm{a}}$ & $2353.0 \pm 1.00^{a}$ & $877.0 \pm 11.50$ & $4137.0 \pm 7.0^{\mathrm{a}}$ & $1.34 \pm 4.01^{\mathrm{c}}$ & $1.75 \pm 3.01^{\mathrm{c}}$ \\
\hline $\mathrm{BC}$ & $675.00 \pm 3.00^{c}$ & $2302.5 \pm 1.50^{c}$ & $633.0 \pm 2.00^{c}$ & $2260.5 \pm 2.50^{c}$ & $873.0 \pm 12.00$ & $4154.5 \pm 7.5^{\mathrm{a}}$ & $1.37 \pm 3.00^{\mathrm{b}}$ & $1.83 \pm 4.01^{\mathrm{b}}$ \\
\hline
\end{tabular}

Note: $\mathrm{CO}=$ control; $\mathrm{GC}=$ diet supplemented with $4 \mathrm{mg} / \mathrm{kg}$ garlic; $\mathrm{CN}=$ diet supplemented with $4 \mathrm{mg} / \mathrm{kg}$ cinnamon; $\mathrm{BC}=\mathrm{diet}$ supplemented with $4 \mathrm{mg} /$ $\mathrm{kg}$ black cumin. Means in the same column with different superscript differ significantly. ${ }^{*}=(\mathrm{p}<0.05) ;{ }^{* *}=$ highly significant $(\mathrm{p}<0.01)$; $\mathrm{NS}=$ not significant.

Table 3. PCV value and some serum biochemical parameters of broilers fed on different sources of plant extracts (mean \pm standard error)

\begin{tabular}{|c|c|c|c|c|c|}
\hline \multirow[b]{2}{*}{ Groups } & \multicolumn{5}{|c|}{ Variables } \\
\hline & $\mathrm{PCV}(\%)$ & $\begin{array}{c}\text { Glucose } \\
(\mathrm{mg} / 100 \mathrm{~mL})\end{array}$ & $\begin{array}{c}\text { Protein } \\
(\mathrm{g} / 100 \mathrm{~mL})\end{array}$ & $\begin{array}{l}\text { Cholesterol } \\
(\mathrm{mg} / 100 \mathrm{~mL})\end{array}$ & $\begin{array}{l}\text { Triglyceride } \\
(\mathrm{mg} / 100 \mathrm{~mL})\end{array}$ \\
\hline $\mathrm{CO}$ & $24.75 \pm 2.55^{\mathrm{d}}$ & $188.29 \pm 9.29^{a}$ & $2.99 \pm 0.04^{\mathrm{b}}$ & $210.00 \pm 7.87^{a}$ & $136.75 \pm 9.30^{a}$ \\
\hline GC & $33.57 \pm 1.60^{\mathrm{bc}}$ & $150.25 \pm 5.40^{c}$ & $3.40 \pm 0.20^{\mathrm{ab}}$ & $155.75 \pm 5.03^{c}$ & $81.75 \pm 4.94^{\mathrm{c}}$ \\
\hline $\mathrm{CN}$ & $39.80 \pm 1.55^{\mathrm{a}}$ & $170.00 \pm 3.39^{b}$ & $4.69 \pm 0.56^{\mathrm{a}}$ & $192.51 \pm 11.08^{b}$ & $100.25 \pm 2.90^{\mathrm{b}}$ \\
\hline $\mathrm{BC}$ & $30.92 \pm 1.08^{c}$ & $176.00 \pm 7.19^{\mathrm{ab}}$ & $4.98 \pm 0.15^{\mathrm{a}}$ & $147.75 \pm 6.76^{c}$ & $97.25 \pm 5.39^{b}$ \\
\hline
\end{tabular}

Note: $\mathrm{CO}=$ control; $\mathrm{GC}=$ diet supplemented with $4 \mathrm{mg} / \mathrm{kg}$ garlic; $\mathrm{CN}=$ diet supplemented with $4 \mathrm{mg} / \mathrm{kg}$ cinnamon; $\mathrm{BC}=$ diet supplemented with $4 \mathrm{mg} /$ $\mathrm{kg}$ black cumin; PCV= Packed cell volume. Means in the same column with different superscript differ highly significant ( $\mathrm{p} \leq 0.01$ ). 
Table 4. Some hormonal values in serum of broilers fed on different sources of plant extracts (mean \pm standard error)

\begin{tabular}{cccc}
\hline \multirow{2}{*}{ Groups } & \multicolumn{3}{c}{ Variables (ug/mL) } \\
\cline { 2 - 4 } & $\mathrm{T}^{*}$ & $\mathrm{~T}^{* *}$ & $\mathrm{TSH}^{* *}$ \\
\hline CO & $1.12 \pm 0.01^{\mathrm{b}}$ & $10.12 \pm 0.27^{\mathrm{c}}$ & $0.202 \pm 0.008^{\mathrm{b}}$ \\
GC & $2.73 \pm 0.23^{\mathrm{a}}$ & $17.27 \pm 0.27^{\mathrm{a}}$ & $0.436 \pm 0.013^{\mathrm{a}}$ \\
CN & $1.75 \pm 0.20^{\mathrm{ab}}$ & $13.14 \pm 0.36^{\mathrm{b}}$ & $0.256 \pm 0.030^{\mathrm{b}}$ \\
BC & $2.75 \pm 0.46^{\mathrm{a}}$ & $18.01 \pm 0.51^{\mathrm{a}}$ & $0.448 \pm 0.020^{\mathrm{a}}$ \\
\hline
\end{tabular}

Note: $\mathrm{CO}=$ control; $\mathrm{GC}=$ diet supplemented with $4 \mathrm{mg} / \mathrm{kg}$ garlic; $\mathrm{CN}=$ diet supplemented with $4 \mathrm{mg} / \mathrm{kg}$ cinnamon, $\mathrm{BC}=$ diet supplemented with $4 \mathrm{mg} / \mathrm{kg}$ black cumin; $\mathrm{T} 3=$ Triiodothyronine T4: Thyroxine; $\mathrm{TSH}=$ Thyroid stimulating hormone. Means in the same column with different superscripts differ significantly; *= $(\mathrm{p}<0.05) ;{ }^{* *}=$ highly significant $(\mathrm{p}<0.01)$.

biological compounds may help to enhance gut digestion. They can also be utilized as beneficial phytobiotic compounds to modify the healthy microflora, reduce harmful microflora population counts such as coliforms, E. coli, and C. Perfringen, stimulate endogenous secretions (enzymes) and lower pH in birds' gut (Wenk, 2003; Khan et al., 2012a; Arif et al., 2019). This condition can bring about a cascade of alterations in birds' responses to disease challenges and nutrients. Even though these metabolic changes did not influence feed intake among groups except in the GC group from 1 day till 6 weeks, which reduced feed intake, which in turn, is of importance from the economic point of view. As a result, this may enable the consumption of the same or lower level of food mass with more metabolizable nutrients via histological optimization in villi length and villi surface area with a decrease of crypt depth (Adibmoradi et al., 2006; Purwanti et al., 2014). Findings of our data are similar to the results of Faghani et al. (2014), who reported a significant increase in body weight and weight gain with a decrease in FCR and feed intake in broiler chickens at 42 days by adding $0.02 \%$ of each GC and $\mathrm{CN}$ in the diet. Also, these results are partly in line with the results of Varmaghany et al. (2015) who stated that diet containing garlic bulbs at 5,10 , or $15 \mathrm{~g} / \mathrm{kg}$ fed to broilers exposed to standard and cold temperature conditions had increased final body weight but without the impact upon FI and FCR. On the other hand, it was found that the inclusion of $0.5 \%$ and $1.0 \%$ dietary GC powder (Puvača et al., 2014) and liquid GC extract in the diet at 1, 1.5, and $2.25 \mathrm{ml} / \mathrm{kg}$ (Brzóska et al., 2015) increased feed intake and did not affect FCR. However, it improved body weight significantly at 42 days in broilers. The results reflect those of Toghyani et al. (2011) and Abo El-Maaty et al. (2014), who found that 2 and $4 \mathrm{~g} / \mathrm{kg}$ of $\mathrm{CN}$ or $\mathrm{GC}$ and $0.5 \mathrm{~g} / \mathrm{kg}$ of $\mathrm{CN}$ respectively increased body weight and improved FCR without influencing feed intake. Our data are inconsistent with the results obtained by Sang-Oh et al. (2013) and Naderi et al. (2014) who stated that $(3,5$, and $7 \%$ ) and $(2.5$ and $7.5 \mathrm{~g} / \mathrm{kg})$ of dietary $\mathrm{CN}$ respectively did not affect body weight and FCR but with a similar amount of consumed food as well. Similarly, concerning the use of dietary BC, it was proven that there was a significant increase in body weight gain accompanying a decrease in FCR for broilers when fed diet supplemented with BC at 2.5 and $5.0 \%$
Table 5. Antibody titers against Newcastle and Gumboro diseases virus of broilers fed on different sources of plant extracts (mean \pm standard error)

\begin{tabular}{ccc}
\hline Groups & $\begin{array}{c}\text { Antibody titer against } \\
\text { Newcastle }\end{array}$ & $\begin{array}{c}\text { Antibody titer against } \\
\text { Gumboro }\end{array}$ \\
\hline CO & $887.50 \pm 33.50^{\mathrm{d}}$ & $1131.50 \pm 31.50^{\mathrm{d}}$ \\
GC & $4110.50 \pm 33.50^{\mathrm{c}}$ & $2128.50 \pm 12.50^{\mathrm{a}}$ \\
$\mathrm{CN}$ & $1365.50 \pm 32.50^{\mathrm{b}}$ & $4227.50 \pm 25.50^{\mathrm{c}}$ \\
BC & $2948.50 \pm 15.00^{\mathrm{a}}$ & $5090.00 \pm 26.50^{\mathrm{b}}$ \\
\hline
\end{tabular}

Note: $\mathrm{CO}=$ control; $\mathrm{GC}=$ diet supplemented with $4 \mathrm{mg} / \mathrm{kg}$ garlic; $\mathrm{CN}=$ diet supplemented with $4 \mathrm{mg} / \mathrm{kg}$ cinnamon; $\mathrm{BC}=$ diet supplemented with $4 \mathrm{mg} / \mathrm{kg}$ black cumin. Means in the same column with different superscripts differ highly significant $(p<0.01)$.

in 28 and 42 days (Khan et al., 2012b), at 10 and $20 \mathrm{~g} / \mathrm{kg}$ from 0-42 days (Ghasemi et al., 2014) and at 10 and 15\% in 6 weeks (Singh et al., 2018).

\section{Haematological and Biochemical Blood Parameters}

Multiple aspects of hematological and biochemical blood parameters could be positively altered by feeding birds with these plant extracts. The plant extracts and their essential oils possess physiological properties, which may stimulate the erythropoietic system to produce red blood cells. These plant-based substances may play an immunizing role in the function of organs pertaining to blood cell syntheses, such as spleen, thymus, and bone marrow. Allicin in GC, cinnamaldehyde in $\mathrm{CN}$, and multiple polyphenols presented in BC affect the performance of intestinal absorption of certain electrolytes such as iron (Abbas \& Ahmed, 2010; Khan et al., 2012a; Tajodini et al., 2015; Kumar \& Patra, 2017), which in turn, might enhance its role in erythropoiesis leading to the increase in the number of red blood cells and enhance PCV as a final result. Therefore, the increase of red cells in the blood stream is correlated with the greater PVC values in the current data (Al-Shammari et al., 2017. ( Another possible reason for the high value of PCV might be associated with high levels of thyroid hormones (T3 and T4) and TSH (Table 4) secreted from the pituitary gland in the majority of our treated groups because there is a positive correlation between PCV and thyroid hormones (Sturkie, 2015) accompanying high metabolic rate and a clear increase in serum protein (Table 3) which was reflected by the greater body weights in treated groups (Table 2). Various substances such as alkaloids, glycosides, flavonoids, carotenoids, terpenoids, etc. are documented to have antidiabetic influence, which can act as safe and substitutional drugs for diabetes mellitus. The hypoglycemic functions of GC and $\mathrm{CN}$ in our data may be due to their activities to regulate blood glucose concentrations by decreasing gluconeogenesis or increasing pancreatic insulin secretion from beta cells (Arif et al., 2014). There is no doubt that numerous plant materials, e.g. GC (Khan et al., 2012a), and essential oils derived from plants (Lee et al., 2004) have hypocholesterolemia properties by their abilities to inhibit the key regulatory enzymes in cholesterol and lipid syntheses, such as hepatic 
3-hydroxy-3-methylglutaryl coenzyme A (HMG-CoA) reductase, malic enzyme, glucose 6 phosphate dehydrogenase, cholesterol $7 \alpha$-hydroxylase, and fatty acid synthetase. Similar data indicated there was a decrease in total cholesterol and triglycerides by $0.5 \%$ dietary GC (Puvača et al., 2014), decrease in cholesterol, glucose, and triglycerides by 1, 2, and 4\% dietary GC (Hossain et al., 2014), increase in total protein and high PCV by 2.5 and $5.0 \%$ dietary BC (Khan et al., 2012b), increase in total protein and decrease in total cholesterol and triglycerides values without a change in glucose level by 1 and $1.5 \%$ dietary BC (Singh et al., 2018) of broiler chickens serum. On the other hand, it was stated that the PCV value was unaffected by 2.5 and $7.5 \mathrm{~g} / \mathrm{kg}$ dietary $\mathrm{CN}$ (Naderi et al.,2014). In addition, contrary to the current findings, Brzóska et al. (2015) mentioned that using liquid garlic extract as feed supplements by 1, 1.5, and 2.25 $\mathrm{ml} / \mathrm{kg}$ of diet for 42 days did not influence cholesterol and glucose levels. However, there was a clear increase in the total protein content of broiler serum for 42 days. Conflicting data was recently achieved by Arif et al. (2019) who stated that using different concentrations of herbal mixtures consisting of black cumin, Moringa oleifera, and chicory seeds at $0.2 \%, 0.4 \%$ or $0.6 \%$ of diet did not change PCV and triglycerides, but it decreased total serum cholesterol in the serum of Cobb broiler chicks.

\section{Thyroid Hormones}

So far, there has been a scarcity of studies pertaining to the impact of the specific plant materials upon thyroid hormonal levels. It was concluded that garlic powders in the diets of broilers reared under normal and cold environmental conditions had no impact on T3 and T4 levels in blood plasma (Varmaghany et al., 2015). Apart from that, Berrama et al. (2017) found that thyroid hormones (T3, T4, and T3/T4 levels) measured in broilers' plasma were not significantly affected by $0.2 \%$ dietary cumin during heat thermal stress conditions at 49 days.

\section{Antibody Titer against Newcastle Disease and Gumboro Disease}

Plant extracts can affect the gut-associated lymphoid tissue which plays the main role in cellular immunomodulation and adjustment of immunoglobulins' secretion in animals (Vidanarachchi et al., 2005) with the increased weight of functional immunological organs such as the spleen, Bursa, and thymus (Khan et al., 2012b; Sang-Oh et al., 2013), and decreased heterophil to lymphocyte ratio (Naderi et al., 2014). Faghani et al. (2014) offered similar observations and stated that antibody titer against Newcastle Disease vaccine of broilers' serum increased in the treated diet with GC or $\mathrm{CN}$ powder. However, based on previous works, no impact of dietary GC or CN was reported on antibody titers against the Newcastle, influenza (Toghyani et al., 2011) Gumboro, and infectious bronchitis in broilers at 21 days (Naderi et al., 2014).

\section{CONCLUSION}

Adding the dietary garlic, cinnamon, and black cumin powders as natural additives in the feed at level $4 \mathrm{mg} / \mathrm{kg}$ diet of broiler chickens resulted in a clear increase in birds' performance, improve blood biochemistry, increase thyroid hormones, and increase Newcastle and Gumboro antibody titers. Based upon the premise, the disturbance of broiler production and physiology may be reduced by dietary supplementation of these safe (plant) extracts through their biological properties and the ability to ameliorate the adverse influence of productive and physiological traits of birds.

\section{CONFLICT OF INTEREST}

The authors declare no conflict of interest with any financial and personal issues or organization in relation to the materials used in this paper.

\section{REFERENCES}

Abbas, T. E. \& M. E. Ahmed. 2010. The use of black cumin in poultry diets. World Poultry Sci. J. 66: 519-524. https://doi. org/10.1017/S0043933910000589

Abo El-Maaty, M. A. Hayam, M. H. Rabie, \& A. Y. El-Khateeb. 2014. Response of heat-stressed broiler chicks to dietary supplementation with some commercial herbs. J. Anim. Vet. Adv. 9: 743-755. https://doi.org/10.3923/ ajava.2014.743.755

Adibmoradi M., B. Navidshad, J. Seifdavati, \& M. Royan. 2006. Effect of dietary garlic meal on histological structure of small intestine in broiler chickens. J. Poult. Sci. 43: 378383. https://doi.org/10.2141/jpsa.43.378

Al-Saleh, I. A., G. Billedo, \& I. E. Inam. 2006. Level of selenium, DL- $\alpha$-tocopherol, DL- $\gamma$ - tocopherol, all trans retinol, thymoquinone and thymol in different brands of Nigella sativa seeds. J. Food. Compos. Anal. 19: 167-175. https:// doi.org/10.1016/j.jfca.2005.04.011

Al-Shammari, K. I. A., J. Batkowska, \& M. M. Gryzińska. 2017. Effect of various concentrations of an anise seed powder (Pimpinella anisum L.) supplement on selected hematological and biochemical parameters of broiler chickens. Braz. J. Poult. Sci. 19: 041-046. https://doi. org/10.1590/1806-9061-2016-0331

Arif, T., B. Sharma, A. Gahlaut, V. Kumar, \& R. Dabur. 2014. Anti- diabetic agents from medicinal plants: A review. Chem. Biol. Lett. 1: 1-13.

Arif, M., Z. Hayat, M. E. Abd El-Hack, M. Saeed, H. M. Imran, A. N. Alowaimer, I. M. Saadeldin, A. E. Taha, \& A. A. Swelum. 2019. Impacts of supplementing broiler diets with a powder mixture of black cumin, Moringa and chicory seeds. S. Afr. J. Anim. Sci. 49: 564-572. https://doi. org/10.4314/sajas.v49i3.17

Berrama, Z., S. Temim, S. Souames, \& H. Ainbaziz. 2017. Growth performance, carcass and viscera yields, blood constituents and thyroid hormone concentrations of chronic heat stressed broilers fed diets supplemented with cumin seeds (Cuminum cyminum L.). Kafkas Univ. Vet. Fak.. 23: 735-742.

Braverman, L. E, R. D. Utigen, Eds, Werner, \& Lngbars. 1996. The Thyroid - A Fundamental and Clinical Text. 7th ED. Philadelphia, Lippinscott- Raven.

Brzóska, F., B. Śliwiński, O. Michalik-Rutkowska, \& J. Śliwa. 2015. The effect of garlic (Allium sativum L.) on growth performance, mortality rate, meat and blood parameters in 
broiler. Ann. Anim. Sci. 15: 961-975. https://doi.org/10.1515/ aoas-2015-0052

Burtis, C. A, E. R. Ashwood, D. E. Bruns, \& WB saunders Co. 2005. Tietz Textbook of Clinical Chemistry and Molecular Diagnostics. $4^{\text {th }}$ ed. Elsevier, St. Louis.

Chowdhury, S. R., S. D. Chowdhury, \& T. K. Smith. 2002. Effects of dietary garlic on cholesterol metabolism in laying hens. Poult. Sci. 81:1856-1862. https://doi.org/10.1093/ ps/81.12.1856

Faghani, M., Y. Rahimian, A. Rafiee, \& A. R. Namjoo. 2014. Effect of garlic and cinnamon in comparison to virginiamycin on performance and some haematological parameters in broiler chicks. Res. Opin. Anim. Vet. Sci. 4: 504-507.

Friedman, R. B. \& D. S. Young. 2001. Effect of Disease on Clinical Laboratory Tests. 4th ed. AACC press, Washington, DC.

Ghasemi, H. A., N. Kasani, \& K. Taherpour. 2014. Effects of black cumin seed (Nigella sativa L.), aprobiotic, a prebiotic and asynbiotic on growth performance, immune response and blood characteristics of malebroilers. Livest. Sci. 164: 128-134. https://doi.org/10.1016/j.livsci.2014.03.014

Ghosheh, O. A., A. A. Houdi, \& P. A. Crooks. 1999. High performance liquid chromatography analysis of the pharmacologically active quinines and related compounds in the oil of the black seed (Nigella sativa). J. Pharmaceut. Biomed. 19: 757-762. https://doi.org/10.1016/S0731-7085(98)00300-8

Haen, P. J. 1995. Principles of Hematology. Published by Brown (William C.) Co, U.S. pp. 400-421.

Hossain, M. A., Md. R. Akanda, M. Mostofa, \& Md. Abdul Awal. 2014. Therapeutic competence of dried garlic powder (Allium sativum) on biochemical parameters in lead $(\mathrm{Pb})$ exposed broiler chickens. J. Adv. Vet. Anim. Res. 1: 189-195. https://doi.org/10.5455/javar.2014.a34

Khan, R.U., Z. Nikousefat, V. Tufarelli, \& S. Naz. 2012a. Garlic (Allium satioum) supplementation in poultry diets: effect on production and physiology. World Poult. Sci. J. 68:417424. https://doi.org/10.1017/S0043933912000530

Khan, S. H., J. Ansari, A. U. Haq, \& G. Abbas. 2012b. Black cumin seeds as phytogenic product in broiler diets and its effects on performance, blood constituents, immunity and caecal microbial population. Ital. J. Anim. Sci. 11(e77): 438444. https://doi.org/10.4081/ijas.2012.e77

Kumar, P. \& A.K. Patra. 2017. Beneficial uses of black cumin (Nigella sativa L.) seeds as a feed additive in poultry nutrition. World Poult. Sci. J. 73: 1-14. https://doi.org/10.1017/ S0043933917000848

Lee, K. W., H. Everts, \& A. C. Beynen. 2004. Essential oils in broiler nutrition. Int. J. Poult. Sci. 3: 738-752. https://doi. org/10.3923/ijps.2004.738.752

Mansoub, N. H. 2011. Comparative effects of using garlic as probiotic on performance and serum composition of broiler chickens. Ann. Biol. Res. 2: 486-490.

Naderi, M., M. R. Akbari, E. Asadi-Khoshoei, K. Khaksar, \& F. Khajali. 2014. Effects of dietary inclusion of turmeric (Curcuma longa) and cinnamon (Cinnamomum verum) powders on performance, organs relative weight and some immune system parameters in broiler chickens. P.S.J. 2: 153-163.

NRC (National Research Council). 1994. Nutrient Requirements of Poultry. 9th ed. National Academy Press, Washington, DC.

Puvača, N., L. J. Kostadinović, D. Ljubojević, D. Lukač, S. Popović, B. Dokmanovć, \& V. S. Stanaćev. 2014. Effects of dietary garlic addition on productive performance and blood lipid profile of broiler chickens. Biotechnol. Anim. Husb. 30: 669-676. https://doi.org/10.2298/BAH1404669P
Puvača, N., L. Kostadinović, D.Ljubojević, D.Lukač, J.A Lević, S.Popović, N. Novakov, B.Vidović , \& O. Đuragić. 2015. Effect of garlic, black pepper and hot red pepper on productive performances and blood lipid profile of broiler chickens. Eur. Poultry Sci. 79. https://doi.org/10.1399/ eps.2015.73

Purwanti, S., Zuprizal, T. Yuwanta, \& Supadmo. 2014. Duodenum histomorphology and performance as influenced by dietary supplementation of turmeric (Curcuma longa), garlic (Allium satioum) and its combinations as a feed additive in broilers. Int. J. Poult. Sci. 13: 36-41. https:// doi.org/10.3923/ijps.2014.36.41

Qin, B., M. Nagasaki, M. Ren, G. Bajotto, Y. Oshida, \& Y. Sato. 2003. Cinnamon extract potentiates in vivo insulinregulated glucose utilization via enhancing insulin signaling in rats. Diabetes Res. Clin. Pr. 62: 139-148. https://doi. org/10.1016/S0168-8227(03)00173-6

Rahmatnejad, E. \& H. Roshanfekr. 2009. Evaluation the effect of several non-antibiotic additives on growth performance of broiler chickens. J. Anim. Vet. Adv. 8: 1757-1760.

Ramadan, M. F. 2007. Nutritional value, functional properties and nutraceutical applications of black cumin (Nigella sativa L.): an overview. Int. J. Food Sci. Tech. 42: 1208-1218. https://doi.org/10.1111/j.1365-2621.2006.01417.x

Sang-Oh, P., R. Chae-Min, P. Byung-Sung, \& H. Jong. 2013. The meat quality and growth performance in broiler chickens fed diet with cinnamon powder. J.E.B. 34: 127-33.

SAS. 2001. Statistical Analysis System. User's Guide Statistics, ver. 8.2. SAS Institute, NC, USA

Singh, P. K. \& A. Kumar. 2018. Effect of dietary black cumin (Nigella sativa) on the growth performance, nutrient utilization, blood biochemical profile and carcass traits in broiler chickens. Anim. Nutr. Feed Technol. 18: 409-419. https://doi.org/10.5958/0974-181X.2018.00038.0

Stanaćev, V., D. Glamočić, N. Milošević, N. Puvača, V. Stanaćev, \& N. Plavša. 2011. Effect of garlic (Allium sativum L.) in fattening chicks Nutrition. Afr. J. Agric. Res. 6: 943-948.

Sturkie, P. D. 2015. Sturkie's Avian Physiology. 6th ed. Edited by: Colin G. Scanes. Academic Press, Elsevier.

Tajodini, M., H. R. Saeedi, \& P. Moghbeli. 2015. Use of black pepper, cinnamon and turmeric as feed additives in the poultry industry. World Poultry Sci. J. 71: 175-183. https:// doi.org/10.1017/S0043933915000148

Toghyani, M., M. Toghyani ,A. Gheisari, G. Ghalamkari, \& S. Eghbalsaied. 2011. Evaluation of cinnamon and garlic as antibiotic growth promoter substitutions on performance, immune responses, serum biochemical and haematological parameters in broiler chicks. Livest Sci. 138: 167-173. https://doi.org/10.1016/j.livsci.2010.12.018

Varmaghany, S., M. A. K. Torshizi, S. Rahimi, H. Lotfollahian, \& M. Hassanzadeh. 2015. The effects of increasing levels of dietary garlic bulb on growth performance, systolic blood pressure, hematology, and ascites syndrome in broiler chickens. Poult. Sci. 94: 1812-1820. https://doi.org/10.3382/ ps/pev148

Vidanarachchi, J. K., L.L. Mikkelsen, I. Sims, P.A. Iji, \& M. Choct. 2005. Phytobiotics: alternatives to antibiotic growth promoters in monogastric animal feeds. Recent Advances in Animal Nutrition in Australia 15: 131-144.

Wenk, C. 2003. Herbs and botanicals as feed additive in monogastric animals. Asian Australas. J. Anim Sci. 16: 282-289. https://doi.org/10.5713/ajas.2003.282

Young, D. S. 2000. Effect of Drugs on Clinical Laboratory Tests. 5th ed. AACC press, Washington, DC. 